Article

\title{
Looking Up to the Stars. A Call for Action to Save New Zealand's Dark Skies for Future Generations to Come
}

\author{
Karolina M. Zielinska-Dabkowska ${ }^{1, * \mathbb{D}}$ and Kyra Xavia ${ }^{2}$ \\ 1 GUT LightLab, Faculty of Architecture, Gdansk University of Technology, Narutowicza 11-12, \\ 80-233 Gdansk, Poland \\ 2 Dunedin Dark Skies Group, Dunedin 9510, New Zealand; kyraxavia@gmail.com \\ * Correspondence: k.zielinska-dabkowska@pg.edu.pl
}

check for updates

Citation: Zielinska-Dabkowska, K.M.; Xavia, K. Looking Up to the Stars. A Call for Action to Save New Zealand's Dark Skies for Future Generations to Come. Sustainability 2021, 13, 13472. https://doi.org/ $10.3390 /$ su132313472

Academic Editor: Boris A. Portnov

Received: 5 November 2021

Accepted: 2 December 2021

Published: 6 December 2021

Publisher's Note: MDPI stays neutral with regard to jurisdictional claims in published maps and institutional affiliations.

Copyright: (c) 2021 by the authors. Licensee MDPI, Basel, Switzerland. This article is an open access article distributed under the terms and conditions of the Creative Commons Attribution (CC BY) license (https:// creativecommons.org/licenses/by/ $4.0 /)$.

\begin{abstract}
The rapid development of technology coupled with humanity's desire to reach beyond terra firma, has resulted in more than 60 years of Outer Space activities. Although the exploration of space has provided many advantages and benefits to society so far, including vast, new information that has greatly added to our understanding of our planet and beyond, unfortunately, mankind's footprint has negative aspects that need to be minimised as much as possible. In recent decades, a major worldwide problem has emerged in regard to the significant increase in light pollution from ground-based illuminations, as well as a lack of proper regulatory frameworks to mitigate the issue in order to protect the night sky and astronomical research. More recently, due to the escalating demand of air space for microsatellites and the rapid development of these new space technologies, as well as unmanned aerial vehicles (UAV), a new problem has arisen connected to visual light pollution (VLP). New Zealand has been especially affected, as, because of its dark skies, it has the third highest number of astronomical observatories in the world. The aim of this research is to identify critical areas for broader investigation; an action plan to improve the impact of new technologies is urgently required, not only at a national level but also worldwide. This is crucial in order to preserve humanity's right to access the night sky and to also enable continual professional and amateur night-time observations for the present and the future, as well as for New Zealand to become a Dark Sky Nation.
\end{abstract}

Keywords: light pollution; visual light pollution; astronomical observations; astrotourism; light pollution abatement; microsatellites; unmanned aerial vehicles; lighting ordinances; sustainable development goals; Māori astronomy

\section{Introduction}

For its small population, land mass, and isolated location, New Zealand has a high number of astronomical observatories [1]. It also has four officially confirmed International Dark-Sky Association's (IDA) Dark-Sky Places [2-5]: the Aoraki Mackenzie International Dark-Sky Reserve (Figure 1), Aotea/Great Barrier Island Dark Sky Sanctuary (Figure 2), Rakiura/Stewart Island Dark Sky Sanctuary (Figure 3), and the Wai-iti Recreational Reserve and Tunnicliff Forest Dark Sky Park, with another 18 places currently aspiring to become recognised dark sky destinations [6].

The International Dark-Sky Association's (IDA) Dark-Sky Places conservation programme was established in 2001 by the IDA - one of the oldest and most recognised grassroots organisations in the world. Its mission is to preserve and protect the night-time environment and the heritage of dark skies through raising awareness about the importance of darkness at night, and to provide education and guidance about quality outdoor lighting [7]. This programme aims to "encourage communities, parks and protected areas around the world to preserve and protect dark sites through responsible lighting policies and public education" [8]. There are five categories that the IDA awards distinctive labels to, in recognition of dark sky efforts: (1) International Dark-Sky Communities, (2) International Dark-Sky 
Parks, (3) International Dark-Sky Reserves; (4) International Dark-Sky Sanctuaries and (5) Urban Night-Sky Places.

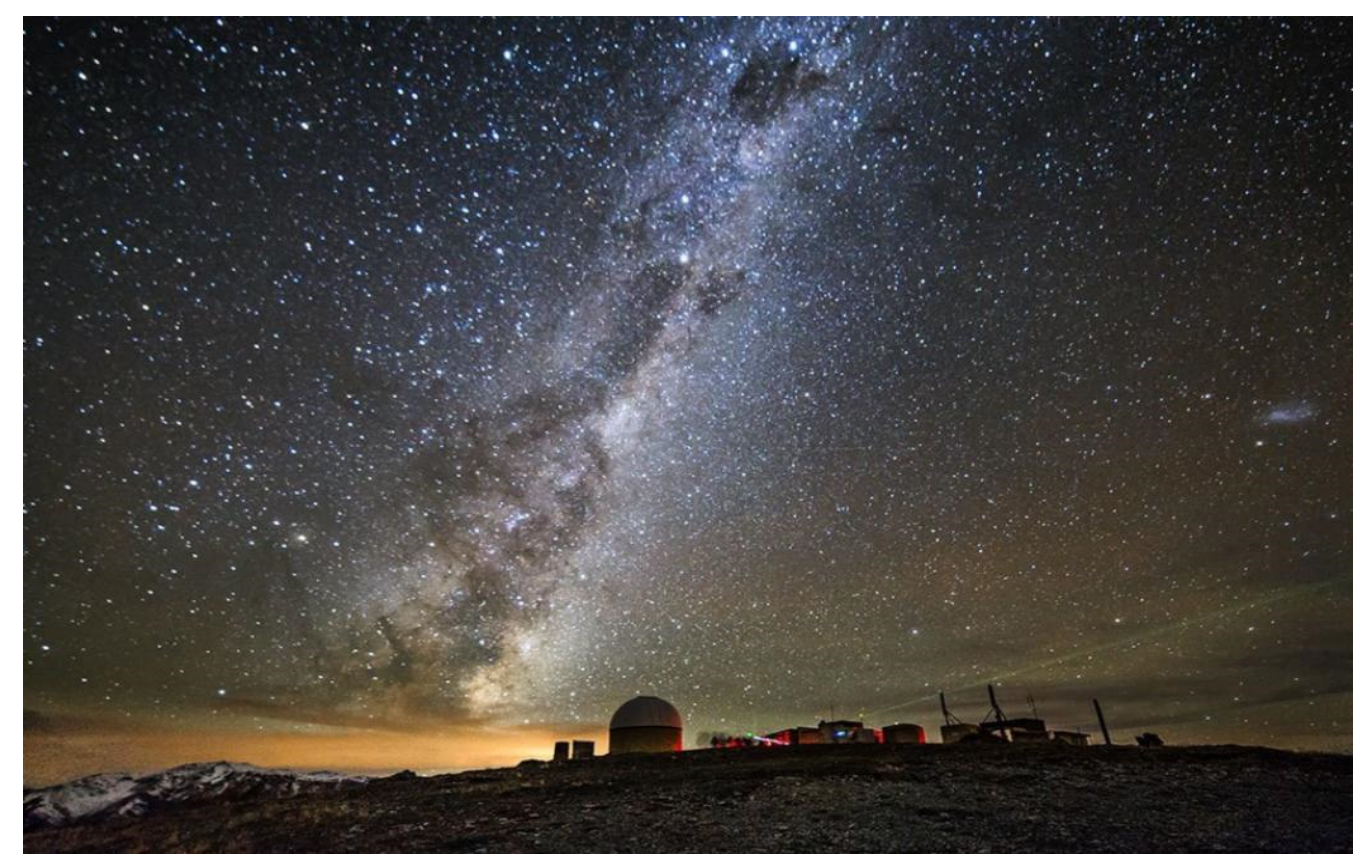

Figure 1. Mt. John Observatory, located within the Aoraki Mackenzie International Dark Sky Reserve (AMIDSR) in New Zealand, including part of the Crux (also known as Southern Cross, visible above the coal sack nebula). The Crux constellation can be seen throughout the year in the Antipodes in a bright part of the Milky Way. Source: Matt Searles, Green Man Creative.

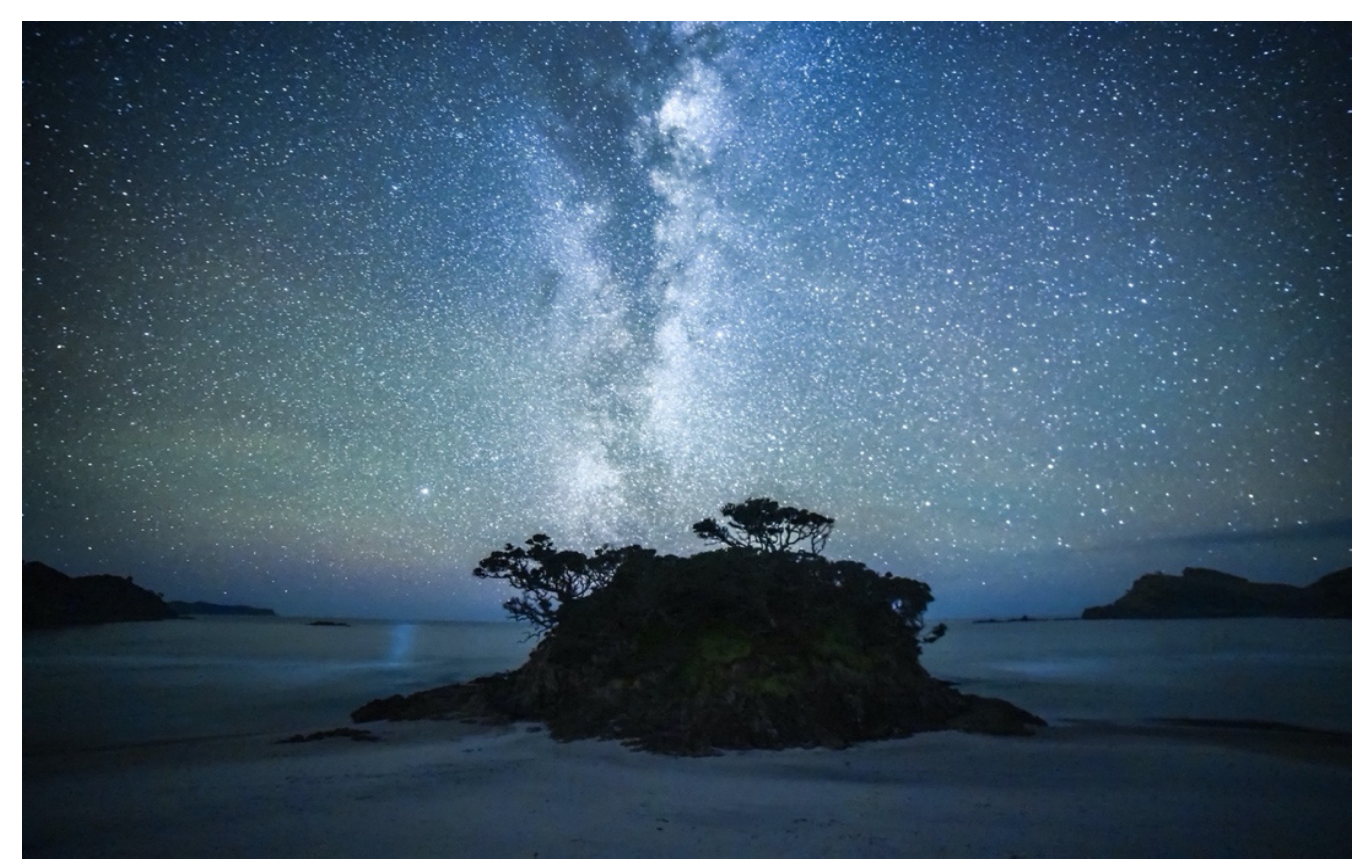

Figure 2. Aotea/Great Barrier Island, New Zealand's first Dark Sky Sanctuary. Great Barrier has no streetlights and all power is self-generated. Source: Mark Russell. 


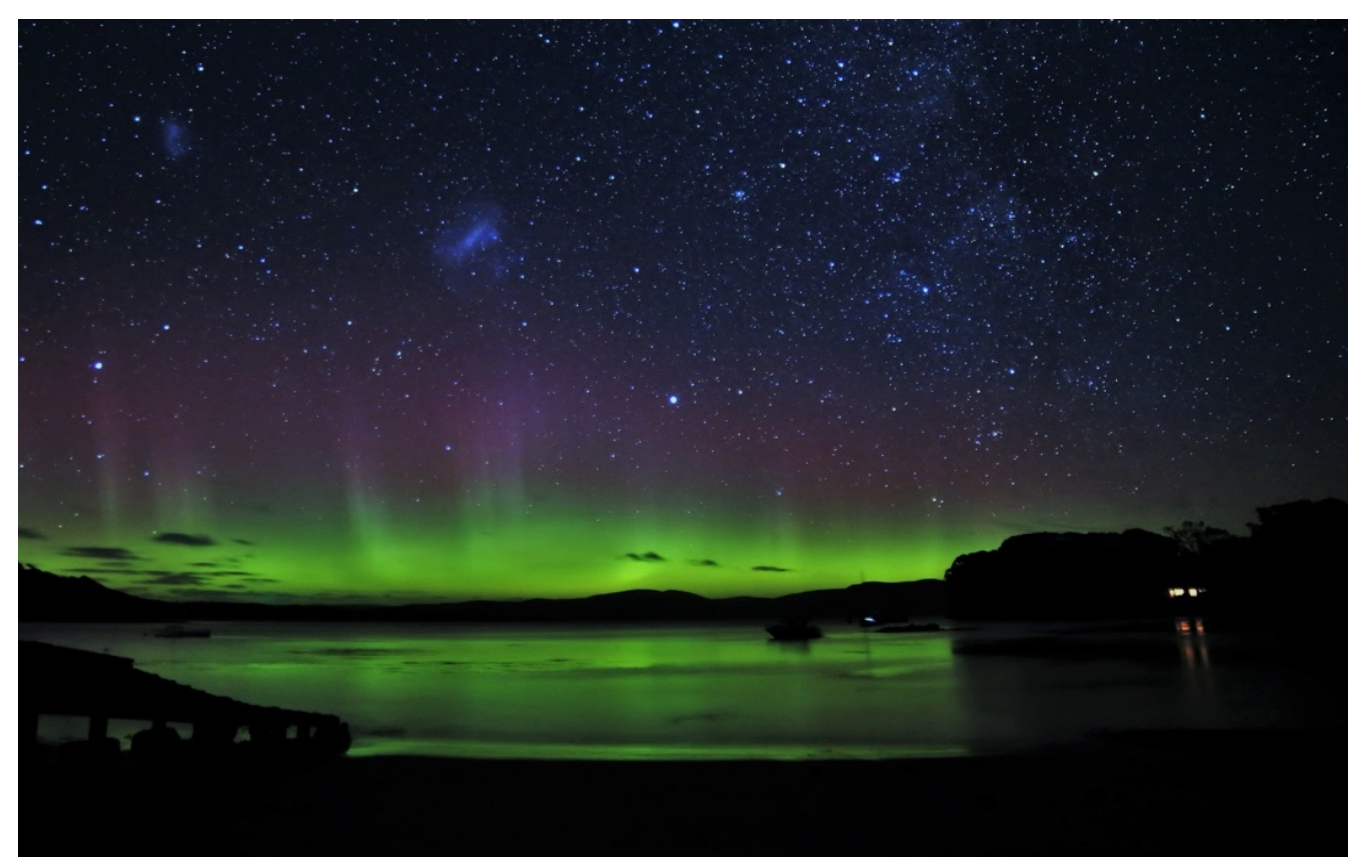

Figure 3. The Aurora australis as seen on Rakiura/Stewart Island-an IDA recognised Dark Sky Sanctuary. (Rakiura means glowing skies in Māori.) New Zealand has two dark sky sanctuaries (both of which are islands) out of ten sanctuaries that exist worldwide. Source: Sandra Whipp, Stewart Island Photography.

According to information provided by Stats NZ Tatauranga Aotearoa, which is the country's government public service department responsible for the collection of statistics, light pollution levels in 2014 were estimated as low (Figure 4). Additionally, " . . based on land area, 74 percent of the North Island and 93 percent of the South Island had night skies that were either pristine or degraded only near the horizon" [9].

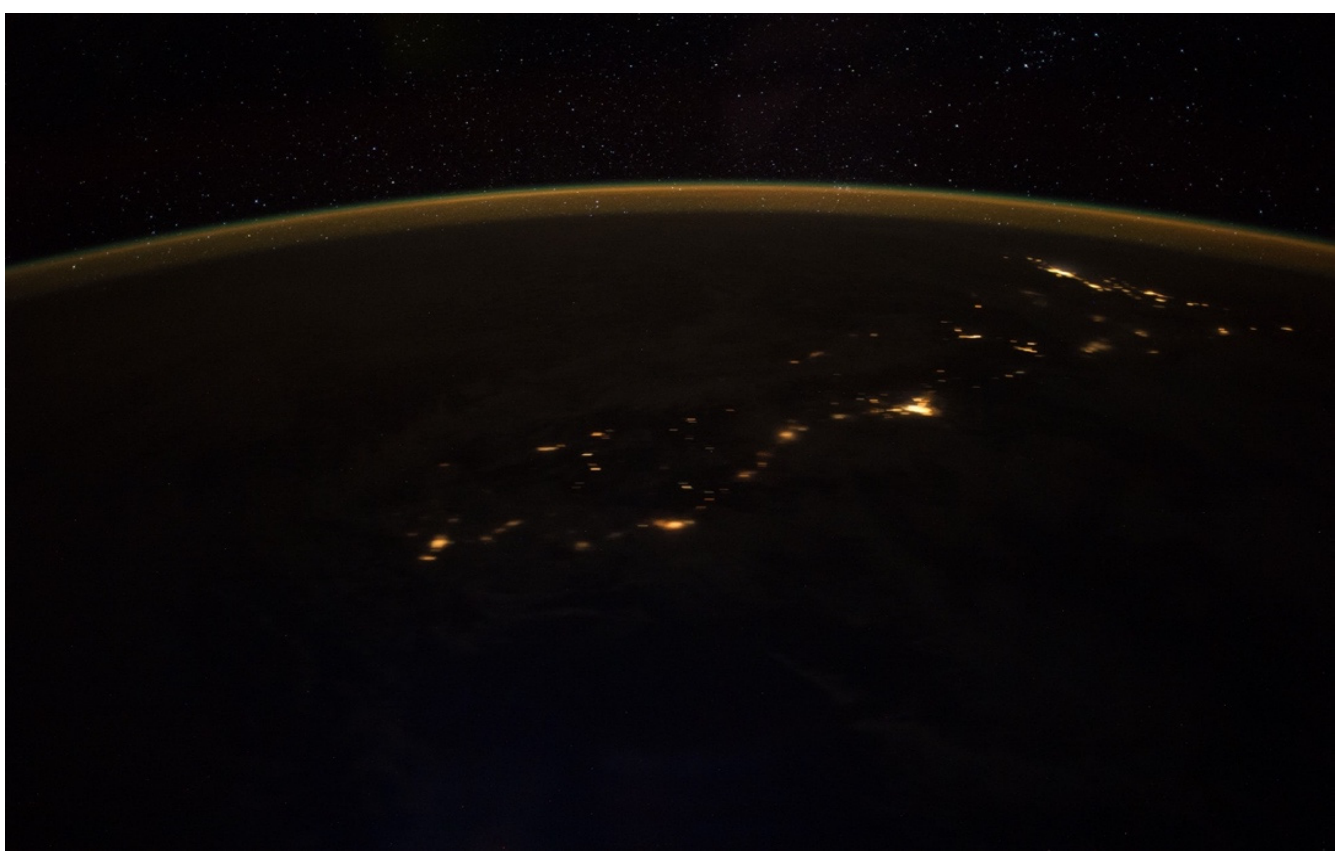

Figure 4. Night-time view of New Zealand taken from the International Space Station on 23rd October 2017, showing how much dark country exists; the only bright areas of illumination are coming from urban areas and other human settlements. Source: The Earth Science and Remote Sensing Unit, NASA Johnson Space Center. 
New Zealand's largest export industry before the COVID-19 pandemic was tourism [10,11], generating 21 percent of profits made from exporting goods and services in the international marketplace. (This includes the sustainable practice of astrotourism, which brings people closer to nature, encourages appreciation for the nightscape, and fosters an interest in astronomy via the preservation and conservation of unpolluted dark skies [12]. The definition of astrotourism also includes tourists who pay to travel into space.)

In 2018, tourism alone achieved $\$ 16.2$ billion, which was 5.8 percent of the New Zealand's gross national product (GDP). This translated into providing new jobs for around 230,000 people (8.4 percent of the total number of people working in the country) [13].

Because thousands of people visit places to observe starry nights [14-16], astrotourism has become a new and important reason to protect the quality of the nocturnal skyscape [17].

Further supporting the public's awareness of the value of the night sky and cultural heritage, Matariki-the Māori name for the constellation Pleiades and the Mãori New Year-became a national holiday in 2021 [18].

The above information aligns with New Zealand's aims to become a Dark Sky Nation. This important concept was made public for the first time at the New Zealand Starlight Conference held in Takapō (Tekapo), in the AMIDSR, in October 2019 [19]. Therefore, to support this goal, the objective of this article is to assess the regulatory frameworks for counteracting man-made light pollution in New Zealand, and to identify possible shortcomings in this area that require legislative intervention, so that this beneficial mission is not unduly hindered.

\section{Definitions Related to Man-Made Light Pollution}

Because of the development of humankind in the Anthropocene era [20], many new phenomena have been discovered, which require correct understanding based on their commonly agreed definitions. In 2001, the first global view of light pollution was published in the "The first World Atlas of artificial night sky brightness" by Cinzano, Falchi and Elvidge, based on radiance-calibrated high-resolution DMSP satellite data and on accurate modelling of light propagation in the atmosphere [21]. This work was then improved upon in 2016, with the first cloud-free mosaic images of the Earth taken by meteorological satellites including the Suomi NPP [22] (Figure 5). These images clearly reveal that 83\% of the world's population is living under light polluted skies [23]. The term light pollution (LP) produced from ground-based illumination was defined as recently as 2011, by the International Commission on Illumination (CIE) in a very general way, as the "sum total of all adverse effects of artificial light" [24]. In addition, man-made sky glow, which disrupts astronomy research and harms natural ecosystems, has been briefly defined as: "part of the sky glow that is attributable to man-made sources of radiation (e.g., outdoor lighting)" [25].

Sky glow, light trespass, glare, and over-illumination are four elements which produce light pollution and directly contribute to the brightening of the night sky (they are well described in the following research work [26]).

Although there exists definitions for pollutions that hinder astronomical observations, such as visual light pollution (VLP) (referred to also as astronomical light pollution (ALP)) and ecological light pollution (ELP), these terms have not yet been officially recognised by the CIE or any other organisation, nor are they used as legal terms. VLP describes the impacts of artificial lighting that impairs the ability to enjoy the night-time view of the starry sky; it also creates constant or temporary changes which degrade the natural environment. ELP can be defined as a continuous or temporary increase in illumination, changes in light spectrum which negatively impact terrestrial and aquatic ecosystems, or a combination thereof. 


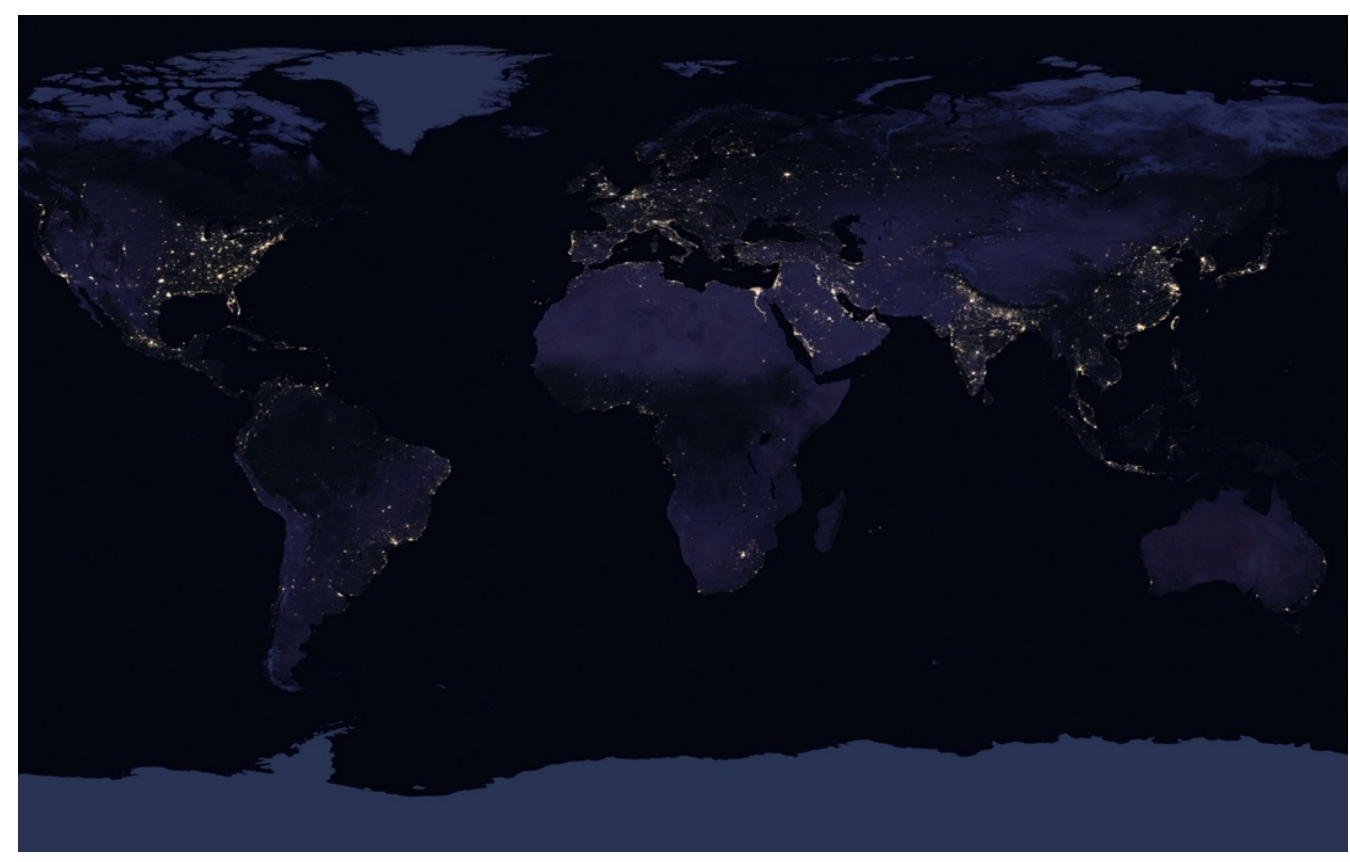

Figure 5. A worldwide composite image of the Earth. It reveals the extent of visible illumination at night as observed in 2016. The effects of light pollution are clearly visible here. This includes sky glow, which spreads far beyond the light sources that produce it. Source: NASA Earth Observatory images by Joshua Stevens, using Suomi NPP VIIRS data from Miguel Román, NASA's Goddard Space Flight Center.

Additionally, Outer Space has been previously defined as: "the physical universe beyond the earth's atmosphere" [27], however, this was before satellites and microsatellites were commercially available and before they began to negatively affect astronomical observations.

The name of the zone of space where technological activities currently take place, in various layers of the Earth's atmosphere, sometimes referred to as Near-Earth Space [28], has not been properly defined, as there is no clear boundary between Earth's atmosphere and Outer Space, and it may extend vastly further from the surface of the planet than was previously thought [29].

All the above terms should constitute the concept of legal language, i.e., should directly be used by the legislator in normative acts.

\section{Research Methodology}

This examination involved an in-depth assessment of published regulatory framework in New Zealand to protect starry skies against light pollution from ground-based lighting installations, and outer and near-Earth space technologies. This included international, national, and local lighting guidelines, procedures, standards and codes, policies, and legal acts.

\section{Analysis and Discussion}

\subsection{New Zealand's Regulatory Frameworks for Counteracting Light Pollution}

There are some actions already being taken in New Zealand to prevent further degradation of the night from light pollution to preserve the country's starry skies and nocturnal landscape for future generations to come [30], and they take the form of international, national, and local guidelines, procedures, standards and codes, policies, and legal acts, as identified in Table 1. 
Table 1. Existing examples of regulatory frameworks in New Zealand to protect stary skies from light pollution created by ground-based lighting installations as well as Outer and Near-Earth Space technologies. Source: authors' elaboration.

\begin{tabular}{|c|c|c|c|}
\hline Category & Year & Name & Type \\
\hline \multirow{6}{*}{ Guidelines } & 1980 & $\begin{array}{l}\text { CIE 001-1980. Guidelines for minimising urban sky glow near } \\
\text { astronomical observatories, by the International Commission on } \\
\text { Illumination (CIE) and the International Astronomical Union (IAU) }\end{array}$ & International \\
\hline & 1997 & $\begin{array}{l}\text { CIE 126-1997. Guidelines for minimising sky glow, by the International } \\
\text { Commission on Illumination (CIE) }\end{array}$ & International \\
\hline & 2017 & $\begin{array}{l}\text { CIE 150:2017. Guide on the Limitation of the Effects of Obtrusive Light } \\
\text { from Outdoor Installations, 2nd Edition, by the International Commission } \\
\text { on Illumination (CIE) }\end{array}$ & International \\
\hline & 2018 & $\begin{array}{l}\text { Best Practice Guidelines for Compliance, Monitoring } \\
\text { and Enforcement under the Resource Management Act 1991, by the } \\
\text { Ministry for the Environment }\end{array}$ & National \\
\hline & 2019 & $\begin{array}{l}\text { CIE 234:2019. A Guide to Urban Lighting Masterplanning, by the } \\
\text { International Commission on Illumination (CIE) }\end{array}$ & International \\
\hline & 2020 & Guide to District Plan lighting rules on Rakiura/Stewart Island & Local \\
\hline Procedures & 2011 & $\begin{array}{c}\text { Model Lighting Ordinance (MLO)_User's Guide, by the International } \\
\text { Dark-Sky Association (IDA) and Illuminating Engineering Society of } \\
\text { North America }\end{array}$ & International \\
\hline \multirow{4}{*}{$\begin{array}{l}\text { Standards } \\
\text { and Codes }\end{array}$} & 2009 & $\begin{array}{l}\text { Code of Practice for City Infrastructure and Land Development } \\
\text { Engineering Standards Manual, Section } 9 \text { Public Lighting by The } \\
\text { Waitakere City Council }\end{array}$ & Local \\
\hline & 2015 & $\begin{array}{l}\text { Australian/New Zealand Standard AS/NZS 1158:2015. } \\
\text { Lighting for roads and public spaces by Standards Australia and Standards } \\
\text { New Zealand }\end{array}$ & National \\
\hline & 2019 & $\begin{array}{l}\text { Australian/New Zealand Standard AS/NZS 4282:2019. Control of the } \\
\text { obtrusive effects of outdoor lighting by Standards Australia and Standards } \\
\text { New Zealand }\end{array}$ & National \\
\hline & 2021 & $\begin{array}{l}\text { Civil Aviation Rules. Part } 101 \text { Gyrogliders and Parasails, Unmanned } \\
\text { Aircraft (Including Balloons), Kites, and Rockets-Operating Rules by the } \\
\text { Civil Aviation Authority of New Zealand (CAANZ) }\end{array}$ & National \\
\hline \multirow{4}{*}{ Policy } & 2005 & $\begin{array}{l}\text { General Policy for National Parks by the New Zealand Department of } \\
\text { Conservation for the New Zealand Conservation Authority }\end{array}$ & National \\
\hline & 2005 & $\begin{array}{c}\text { Conservation General Policy by the New Zealand Department } \\
\text { of Conservation } \\
\text { for the New Zealand Conservation Authority }\end{array}$ & National \\
\hline & 2010 & $\begin{array}{l}\text { New Zealand National Coastal Policy Statement (2010) Policy } 13 \\
\text { Preservation of natural character by the New Zealand Department } \\
\text { of Conservation }\end{array}$ & National \\
\hline & 2021 & $\begin{array}{c}\text { The Artemis Accords: Principles for Cooperation in The Civil Exploration } \\
\text { And Use Of The Moon, Mars, Comets, And Asteroids For Peaceful } \\
\text { Purposes by NASA/US and the New Zealand Space Agency }\end{array}$ & Transnational \\
\hline \multirow{5}{*}{ Legal Acts } & 1967 & $\begin{array}{l}\text { Treaty on Principles Governing the Activities of States in the Exploration } \\
\text { and Use of Outer Space, including the Moon and Other Celestial Bodies } \\
\text { (Outer Space Treaty) by the United Nations Office for Outer Space Affairs }\end{array}$ & Transnational \\
\hline & 1981 & The Mackenzie District Lighting Ordinance & Local \\
\hline & 1991 & Resource Management Act 1991 by the Government of New Zealand & National \\
\hline & 2015 & Environmental Reporting Act 2015 by the Government of New Zealand & National \\
\hline & 2017 & $\begin{array}{l}\text { Outer Space and High-Altitude Activities Act } 2017 \text { (2017/29) by the } \\
\text { Government of New Zealand }\end{array}$ & National \\
\hline
\end{tabular}




\subsubsection{Light Pollution from Ground-Based Installations}

In New Zealand, the Resource Management Act (RMA) 1991 [31] now acts as the main legislative umbrella over resource use and environmental matters (land use resource management goals and methods for achieving these). Although, since its introduction, numerous amendments have been made. The Act delegates administrative responsibility to Regional and District Councils. Regional Councils are required to prepare policy statements, which communicate the resource management issues within their areas. Both Regional and District Councils then devise plans, which provide the rules and strategies to facilitate the specific aims of the regional policy statement [32].

Under the RMA, decision-making about environmental issues is mostly left to local councils and their communities. There are plenty of ways for the public to be involved in what occurs. For instance, when councils create, amend, or vary plans, they are required to gather input from their communities. Councils also need to ensure the community has the chance to provide input into resource consent decision making, where appropriate. This means that local councils and their communities can directly be involved in environmental decision-making, as the RMA gives them the right to do so.

Local lighting ordinances are also a crucial tool for setting reasonable limits on light pollution. Once created, towns and cities can adopt and enforce them to conserve energy, and to help reduce light pollution.

The first lighting ordinance in New Zealand was created in 1981 and was incorporated into the Mackenzie District Plan. It is now part of the Resource Management Act [33]. It was the lighting ordinances and the success of astrotourism which helped to protect the night sky above the townships of Takapō (Tekapo), Mt Cook, Twizel, and Fairlie within the International AMIDSR, with the approval for the installation of phosphor-converted amber (PCA) 2200 K LEDs in the recent LED retrofit. Other recognised IDA Dark Sky places in New Zealand, such as Rakiura (Steward Island), are also integrating lighting guidance in the form of local policy in their long-term district plan [34]. The Wairarapa region [35], Selwyn district [36], as well as townships such as Naseby [37], Kaikōura, Oxford, and West Melton are also implementing similar changes, and more are following suit. Although the Central Otago region does not yet have any official IDA recognised destinations, the Central Otago District Council (CODC) has taken steps to establish its own Public Spaces Lighting Policy [38].

Another good example of citizen action is the city of Dunedin. Despite having no lighting ordinances, the consistent grassroots efforts of the Dunedin Dark Skies Group to protect ecology and the nightscape resulted in the city rejecting the formerly planned $4000 \mathrm{~K}$ LEDs. Instead, the council made a special business case to the NZTA for $3000 \mathrm{~K}$ for most of the city, and the Otago Peninsula and the small coastal towns north of the city installed PCA $2200 \mathrm{~K}$ LEDs. The protection of ecology via LEDs that emit lower amounts of disruptive, light polluting blue wavelengths of light was a first for New Zealand [39,40].

For astronomical sites, there are specific guidelines from the International Commission on Illumination (CIE) CIE 001-1980 [41], CIE 126-1997 [42] and CIE 150:2017 [43], which define specific approaches to minimise light pollution, especially sky glow around astronomical observatories, and to also limit the effects of obtrusive light from outdoor installations. However, these were created with older light sources in mind, not lightemitting diodes (LEDs), which are a new lighting technology. These new light sources are far brighter due to their excess luminance and they also emit broad spectrum light, which cannot be filtered out of images taken by astronomers. Furthermore, LEDs contain higher levels of light polluting short blue wavelengths of energy, which can bounce back from the ground to then scatter in the atmosphere, increasing light pollution, which negatively impacts astronomical observations [44].

For decades, the township of Takapō (Tekapo) used low-pressure sodium (LPS) lamps to protect astronomical research undertaken at $\mathrm{Mt} \mathrm{John} \mathrm{observatory,} \mathrm{and} \mathrm{the} \mathrm{only} \mathrm{new} \mathrm{LED}$ equivalent that currently exists that has a similar spectral power distribution is narrowband amber (NBA). Unfortunately, in comparison to the older LPS, which are being phased 
out, quality NBA luminaires are currently costly and not widely available. Acceptable replacement LEDs for LPS should also have special optics to mitigate excess luminance and non-uniform distribution, and appropriate lighting levels must be applied as well, so LED retrofits do not add to or increase unnecessary light into the environment and atmosphere.

There are also New Zealand lighting standards, e.g., AS/NZS 1158:2015 [45], which addresses technical lighting parameters and requirements, which must be fulfilled for designing lighting for roads and public spaces, as well as the AS/NZS 4282:2019, which provides guidance to control the obtrusive effects of outdoor lighting. It is worth noting the Waka Kotahi New Zealand Transport Agency (NZTA) has also created the following guidelines in their document M30 Specification and guidelines for road lighting design [46], in which they state that all lighting applications must demonstrate adherence to the principles of the International Dark-Sky Association (IDA). There appears to be a misunderstanding about this, as they continue to recommend LED light sources that have a correlated colour temperature (CCT) of $4000 \mathrm{~K}$, and not $3000 \mathrm{~K}$ or below, as was recommended by IDA until February 2021. It is crucial to understand that the IDA has now improved and updated their guidance. This not only reflects mounting research about the potential harm caused by broad spectrum LEDs, but it also acknowledges the increasing demand for safer, responsible lighting, as well as the wider availability of luminaires that have a much more appropriate spectral power distribution (SPD). This means the IDA now recommends outdoor lighting of $2200 \mathrm{~K}$ and below, combined with other important criteria to mitigate light pollution [47].

Furthermore, the latest edition of the NZTA's M30 list of approved luminaires (March 2021), which councils had to choose from by 2021 in order to receive substantial funding (85\%) [48], only includes cool white LEDs from 3750-4250 K [49]. There are no approved phosphor-converted amber (PCA) LEDs or filtered LEDs (FLED), nor are there any NBA LEDs on this list. While councils were able to make a special business case to the NZTA for more appropriate, dark sky compliant LEDs, the majority were unaware that this was possible. Unfortunately, these failures have generated much confusion for decision-makers and contractors, as well as effectively stymying local efforts to protect the dark night sky (and ecology) in places including Christchurch, Kaikoura, Geraldine, and Oamaru, as well as the small town of Naseby, which had full community support for $2200 \mathrm{~K}$.

Existing lighting ordinances, best lighting practices, and local district policy to protect the nocturnal landscape and the night sky in certain places in New Zealand, can and should be widely adopted elsewhere in the world, because the numerous problems of light pollution, involving sky glow, light trespass, glare, and over-illumination, can be addressed in the same way.

Most importantly, responsible lighting provides many benefits, such as saving energy, supporting human health and the biodiversity of ecosystems, being better for the environment, improving safety, enhancing life quality, and making communities more liveable.

This is a practical and functional way to reduce the adverse harm and impact of ALAN, whilst making urban spaces safer and more user-friendly, and protecting rural and pristine natural areas.

Furthermore, unlike other environmental pollutants that are difficult to remove, responsible lighting can make an immediate and significant improvement. This involves choosing the most suitable light source or sources, using fully shielded, full cut-off fixtures, positioning them carefully to direct light only to where it is needed, keeping lighting levels low, limiting the number of light sources to avoid over-lighting, ensuring lighting is evenly and softly dispersed, only operating lights when they are required, applying curfews, automatic sensors and timers, choosing light sources that have a safer colour spectrum $(2200 \mathrm{~K})$, and, when possible, avoiding white LED light sources that emit disruptive blue wavelengths of light. These steps combine to help ensure lighting is safe, appropriate, and well-controlled. 


\subsubsection{Light Pollution from Outer and Near-Earth Space Technologies}

Access to a pristine night sky is at risk of being lost if corrective measures are not taken, because New Zealand is also experiencing a boom in another area: that of space technology. According to reports, New Zealand is the fourth largest player in the world [50]; indeed, the space industry has provided 12,000 jobs and earned $\$ 1.75 \mathrm{bn}$ for the New Zealand economy in the 2018-2019 financial year [51]. Unless effective remedial measures are made, satellites could soon outnumber many visible stars, not only in New Zealand, but all around the world, as they constantly orbit the Earth [52].

The basic legal framework of international space law ratified in 1968, by New Zealand, is the Treaty on Principles Governing the Activities of States in the Exploration and Use of Outer Space, including the Moon and Other Celestial Bodies (Outer Space Treaty) by the United Nations Office for Outer Space Affairs [53]. Article IX states that: "States Parties to the Treaty shall pursue studies of outer space, including the moon and other celestial bodies, and conduct exploration of them so as to avoid their harmful contamination and also adverse changes in the environment of the Earth resulting from the introduction of extra-terrestrial matter and, where necessary, shall adopt appropriate measures for this purpose". In this case, light pollution should be seen as a harmful contaminant because artificial light causes adverse changes to the Earth's atmosphere [54,55].

Until recently, New Zealand did not have any national space law concerning activities in Outer Space, such as exploration and its use. In order to create space policy and regulation in this area, the NZ Space Agency was created in 2016, as the lead government agency. In 2017, the government of NZ established the Outer Space and High-altitude Activities Act, in order to regulate, through licences or permits, launches into outer space, launch facilities, high-altitude vehicles (HAVs) and payloads. However, there is no mention in this Act of the impact that such activities may have on the night sky and astronomy [56,57]. In 2021, a high level policy document called the Artemis Accords: Principles for Cooperation in The Civil Exploration and Use of The Moon, Mars, Comets, And Asteroids For Peaceful Purposes was signed by NASA/U.S. and the New Zealand Space Agency, which establishes a practical set of principles to guide space exploration cooperation among nations participating in NASA's 21st century lunar exploration plans [58]. Of its points, one addresses the avoidance of the "harmful contamination of outer space and/or adverse changes to the Earth's environment resulting from the activity". Moreover, Māori interests and values have been motioned: "Knowledge of outer space, known as tātai arorangi, is a fundamental aspect of mātauranga Māori. It features significantly in Māori indigenous knowledge and values, such as whakapapa, which provides that our genealogical origins are linked to the beginning of the Universe; kaitiakitanga, which requires guardianship of outer space and protection of its resources; and wairuatanga, which is focused on the spiritual connection between the Earth and the universe derived from Māori cosmology ... " [59]. Thus far, it also seems that there is no impediment to enacting a policy such as this, because there is nothing in the law expressly prohibiting it.

Another regulatory framework by New Zealand's national aviation authority, the Civil Aviation Authority of New Zealand (CAANZ), defines the use of unmanned aerial vehicles (UAV), such as drones [60]. Currently, they are only allowed to be flown during the day, but this might soon change if the popular use of drones for large light show, as seen overseas, continues unchecked.

The above analysis highlights that existing prevention measures to counteract manmade light pollution is ineffective. Although ground-based installations are sometimes regulated by separate legal acts of statutory rank, ordinances, urban lighting masterplans adopted by the local authorities, and environmental and nature protection legislation [61], further inquiry and scholarly work is required to address the existing gaps.

Of note, the United Nations acknowledges that terrestrial light pollution is within the remit of its Committee on the Peaceful Uses of Outer Space (COPUOS), as it solicited a report on the subject, along with satellites and radio astronomy interference, from the astronomy community in 2020 [62]. The severity of light pollution has elevated concerns to a level where dedicated, systematic policy approaches are exigent. It is no longer sufficient 
to house light pollution regulations within environmental policies or land use ordinances. There is now substantial evidence to support this conclusion.

\subsection{Aspects Requiring Broader Investigation and an Action Plan for Improvement}

There are five critical aspects where broader investigation and an action plan for improvement are urgently required in New Zealand and beyond, as light extends well outside national borders. Some topics have been addressed in the Declaration in Defence of the Night Sky and the Right to Starlight known as the La Palma Declaration, which was proclaimed in 2007 in La Palma, Spain [63].

4.2.1. The Impact on the Visibility of the Dark Night Sky, and Celestial Bodies as an Ancestral Global Commons

New Zealand is home to the indigenous Polynesian people (Māori), whose cultural heritage has a strong association to, and extensive astronomical knowledge of the night sky, including the Moon, planets and the stars [64] (Māori astronomical knowledge is known as tātai arorangi [65]). This understanding is skilfully integrated into several aspects of their traditional lives and cultural practices [66-68].

As the visibility of celestial bodies (starlight) and Galaxies such as the Milky Way, which can be seen using the naked eye, are considered a natural resource of immense historical and cultural significance to this native group, it is of the utmost importance to protect it from progressive degradation. This involves reducing the levels of light pollution that originate from urban settlements, as well as farming, abattoirs, and the dairy industry in rural areas.

It is now also believed that observations of the night sky and the right to starlight is an indispensable part in the progress of all cultures and civilisations, as stated in the 2007 La Palma Declaration, which says: "The right to an unpolluted night sky that allows the enjoyment of the contemplation of the firmament should be considered an inalienable right of humankind equivalent to all other environmental, social, and cultural rights, due to its impact on the development of all peoples ... " [69]. Until today, no country has enacted La Palma Declaration's recommendations into law. The United Nations has taken no further action on the recommendations. Can any of this make a difference if the world does not choose to embrace it?

Respect for starry skies and preservation of the nightscape is now more urgent than ever as Matariki becomes a public holiday. If guidelines are not put in place to ensure that celebrations that value the darkness required to actually see this small constellation, and to uphold the fact that respect for the night is part of Māori culture and heritage, New Zealand risks further disconnection from these precious assets. This lack of awareness has already been demonstrated by Christchurch recently announcing in the media that parts of the city will be lit up with lighting installations, projections, illuminated artworks and fireworks. (The name of the event, Tīama Mai, translates to illuminate or bring light, and it will be the city's first lighting event held specifically to coincide with Matariki) [70]. In the near future, it is also highly likely that drone light displays could be involved in similar such events.

\subsubsection{The Impact on Professional and Amateur Astronomical Observations}

New Zealand's observatories benefit from their location. (1) There is a relative lack of large observatories in the Southern Hemisphere in comparison to the Northern Hemisphere (the world needs New Zealand's observatories, to increase the coverage of targets at high southern declinations, and to allow some to be dedicated to the long-term monitoring of such fields); (2) for studying (or discovering) targets that vary in brightness or spectrum with time; New Zealand's longitude gives important phase coverage as the Earth rotates, filling the gap between the Hawaiian and Australian observatories. (E.g., it was for this reason that the famous Supernova SN 1987A was independently co-discovered in NZ); and lastly (3) New Zealand's latitude makes the South Island one of the only land masses outside of Antarctica from which the Aurora Australis can be seen and studied on occasion. 
(Latitude, being closer to the south pole than the ESO telescopes, means that the area of the southern pole is closer to the zenith).

Moreover, due to the low population density, especially in the South Island, New Zealand has really dark skies which are protected. Based on recent research, the global satellite observable light emissions in New Zealand increased from 1992 to 2017 by only 10 percent [71].

Domestic astronomical observatories in predominantly dark sky sites add a high impact to its professional astronomy output, which is confirmed in various discoveries (listed below) and numerous scientific publications [72].

Professional astronomy has developed in New Zealand in the past fifty years; before that, this field dealt mainly with optical observations of the sky and therefore, the discoveries of the XX-century in worldwide astronomical research were by amateur astronomers using relatively small telescopes. The following examples of discoveries by amateur astronomers show that New Zealand is in the forefront of astronomical education, as it also has more amateur astronomical societies per head of population than any other country [73]. John Grigg discovered four comets in the first decade of XX-century. He is internationally known for his co-discovery of the periodic comet 26P/Grigg-Skjellerup in 1902 [74]. In 1910, David Kennedy and two seminarians used the Meeanee observatory to take photographs of Halley's Comet, which were among the best in the world [75]. Amateur astronomer Albert Jones discovered the comet C/1946 P1 in 1946 and in 2000, he co-discovered, the comet C/2000 W1. In 1987, he co-discovered the supernova SN 1987A in the Large Magellanic Cloud [76]. In 2009, Supernova 2009gj in NGC 134 was discovered by another amateur astronomer Stuart Parker [77,78]. In 2005, Grant W. Christie and Jennie McCormick, both amateur astronomers, caught the microlensing event OGLE-2005-BLG071 with their telescopes. Their recorded data, together with those of the professional astronomers, confirmed a half-magnitude dimming of the background star caused by the gravity of a planetary-mass object [79]. Moreover, there are many asteroid occultation amateurs who contribute their findings to a world data bank and these data are used by NASA to track asteroid traffic in the face of space launches and space probe orbits.

Of the most recognised astronomical research observatories in New Zealand, one is the University of Canterbury Mount John Observatory (UCMJO), previously known as Mt John University Observatory (MJUO), established in 1965. It operates five large telescopes that are in regular use. In June 2008, using the MOA-II telescope, the observatory discovered the smallest planet known outside of our Solar System called MOA-2007-BLG-192Lb [80]. Recently, in 2020, an Earth-like planet was discovered by New Zealand astronomers [81].

Due to man-made light pollution from outdoor illumination, microsatellites, and UAV's such as drones, there is a high risk to the thirty astronomical observatories [69] that exist in New Zealand, to perform their research in the future, encourage public engagement, and to continue valuable outreach in the local community.

These new technologies use air space from the troposphere $(0-10 \mathrm{~km}$ upwards $)$ to the stratosphere $(10-50 \mathrm{~km})$ for drones, and proposed stratospheric platforms to beam 5G signals to the Earth [82], and to also use the space above the stratosphere to deploy thousands of mega-constellations of satellites in low-Earth orbit, to enable 5G [83,84].

The recent visual light pollution caused by thousands of these new satellites prevents access to a naturally dark sky. Their invisible radio frequencies also threaten astronomy research [85] and can even damage or destroy sensitive radio astronomy receivers [86].

Another issue is the popular new use of hundreds of drones for large theatrical lightshows $[87,88]$. This means the "protection of the astronomical quality of areas suitable for the scientific observation of the Universe must be given priority in national and international scientific and environmental policies" [89].

\subsubsection{The Impact on Public Health-Exposure to Artificial Light at Night (ALAN)}

ALAN exposure is generally detrimental to human health [90], including one of the most obvious issues of unwanted light trespass and spill light [91] from outdoor 
illumination into people's homes, which adversely affects sleep [92]; however, drones create another dilemma.

There are increasing reports of aviation accidents caused by drones [93]. Additionally, one aspect which has not been given enough attention and concern are drones used for large light shows and displays. Although the novelty factor is high for this new form of entertainment, we need to weigh the negative consequences, and question whether this use of technology is even necessary. Lighting at night needs to serve an important and useful function due to its adverse impact on health, ecology, the environment, and the night sky, which is why it is important to proceed with utmost caution, and rethink the use of illumination for entertainment alone. If this form of lighting becomes commonplace before effective regulations are established, it will be much harder to control and manage.

\subsubsection{The Impact on Flora and Fauna}

Research now confirms the adverse impact of ALAN at night on ecology, especially on natural ecosystems and biodiversity [94,95]. All known behaviours, including feeding, spawning, mating, nesting, navigation, and rest, as well as the flowering, fruiting, reproduction, and growth of plants, and the behaviours of microorganisms, can be disrupted, which has a negative cascading effect upon biodiversity. Most importantly, we are still discovering unexpected and vital links to darkness, light and behaviour, such as the fact that dung beetles navigate using the low light levels of the Milky Way [96]. These discoveries highlight the surprising degree of sensitivity many species have to ALAN.

In fact, ecologists explain that light pollution can be so faint it cannot be detected by the human eye, yet it could still jeopardise the $60 \%$ of invertebrates and $30 \%$ of vertebrates that are nocturnal and exquisitely sensitive to light [97]. Preserving the nocturnal land and skyscape is particularly important in New Zealand due to the country's unique native flora and fauna, especially for nocturnal species. This includes many of the 1983+ different types of moths [98], the kākāpō (the world's only nocturnal parrot), numerous species of ngaokeoke (velvet worm) [99], kororā (little blue penguin) [100], two species of pekapeka (bats) [101], looper caterpillar [102], ruru owl [103], five species of kiwi [104], titiwai (glowworms) [105] and 100+ species of wētā (large flightless crickets) [106], to name just a few.

Reducing the pressure of manmade environmental burdens upon these species is essential because many are endangered. In addition, even those that are not formally classified as "endangered" are often under rapidly mounting environmental pressures, the greatest of which, on a global scale is, climate change. Although light itself might not be the sole cause of a species going extinct, it could very well be that crucial influence that pushes it towards extinction.

Furthermore, many ecotourism ventures rely upon the existence of certain nocturnal wildlife species to generate income; for instance, firefly tours around the world [107], and in New Zealand, boat tours during the day to watch the Dusky dolphins near Kaikoura [108], which are active at night when they prey for food. Furthermore, vulnerable migrating nocturnal seabirds, such as the endangered New Zealand storm petrel, Westland petrel, and the threatened Kaikōura tìtî (Hutton's shearwater, which is the only seafaring bird in the world to nest in sub-alpine environment), as well as many other species, are particularly vulnerable to being attracted to ALAN, only to be then harmed or killed when they become grounded due to the prevention of their natural flight patterns from man-made illumination on land $[109,110]$.

It is short-sighted for drones to be introduced into any environment where ecology is already under threat [111,112], particularly when there are artists who already use drones for creating light sculptures in dark environments, which impacts fauna [113]. Therefore, "control of obtrusive light must be a basic element of nature conservation policies due to its impact on several species, habitats, ecosystems, and landscapes" [114]. 


\subsubsection{The Impact on Degradation of Earth's Near-Space Environment (Space Pollution)}

Space pollution [115] is an accepted fact, with the slow degradation of this environment since 1957, and the launch of the first satellite [116]. There are currently more than 20,000 artificial objects in orbit above the Earth. These can be divided into two categories: (1) functional objects in the form of operational satellites [117] and (2) non-functional objects in the form of orbital debris, defined by NASA as "any man-made object in orbit about the Earth which no longer serves a useful function" [118]. The latter category is already a serious problem, as pieces in the form of non-functional spacecraft, abandoned launch vehicle stages, mission-related and fragmentation debris, and other physical elements, such as tools lost by astronauts in space, or even fragments from collisions etc., still orbit around the Earth.

If this worrying issue is not resolved, researchers warn that there is the high risk of losing orbital pathways around Earth used by artificial-satellites, as it will be impossible to use them without catastrophic collisions [119]. These pathways in near-Earth Space are economically important (it takes less effort, fuel, and expense to deliver the equipment to this close orbit). The International Space Station (ISS) has already been forced to take urgent action in order to avoid clashing with such objects [120] and there are more collisions between smaller objects that are occurring on a regular basis [121,122].

\section{Conclusions-An Urgent Call for Action}

Due to the presented issues, an urgent call for action is required. Firstly, it is essential to establish internationally approved regulatory frameworks to mitigate light pollution from ground-based artificial light sources. As yet, there are no established methods to physically measure light pollution, especially sky glow [123], and there are no legal requirements to prevent it. Secondly, it is necessary to establish internationally approved regulatory frameworks to protect the night sky from the uncontrolled rapid development of space technologies. The first attempt to try and obtain some global consensus on this topic from various representatives of international organisations was in 2020, during the Dark and Quiet Skies for Science and Society Workshop [124]. However, because of the time it takes to create and establish international policy, it is unlikely an agreement will be reached on restrictions in time to prevent the vast accumulation of debris in space from LEO satellite megaconstellations. This might change if the UN acts immediately to add Access to Dark Skies whilst reducing light pollution to the United Nations' 17 Sustainable Development Goals (SDG) [125] as a new goal. At the moment, the term light pollution is not even mentioned in any of the existing 169 targets contained within the 17 goals [126]. This would allow for international litigation (the judicial resolution of claims in the International Court of Justice) [127].

The idea of "democratising access to space exploration" [128] should not mean enabling a Wild West of the XXI century. Rather, it should help pioneer a worldwide sustainable approach to space exploration via international collaboration. For example, the initiative promoted by the ESA $[129,130]$. It is critical to consider the adverse impact of future space tourism. The many successful commercial tests demonstrate that this goal is not a distant dream [131], and it is imperative that mankind act now to legally regulate this sector before we face serious consequences.

Underlying all of this, however, is the necessity of obtaining support from the Department of Conservation and the government in New Zealand, as a Dark Sky Nation is congruent with, and supportive of biodiversity, sustainability, and wellbeing, which strengthens New Zealand's international image and reputation [132]. New Zealand cannot have it both ways; both upholding nature as a priority but exploiting it in a destructive and non-renewable way.

Guidance for external illumination has been provided by the IDA in the form of five principles of responsible outdoor lighting (Figure 6), unfortunately, this only relates to man-made illumination on the ground. It would be useful indeed, for the International Astronomical Union (UIA) [133], together with the United Nations Office for Outer Space 
Affairs [134], to produce similar recommendations for the man-made light pollution that is produced in Near-Earth Space and Outer Space, which is visible from Earth. These future principles should then be adopted by governments worldwide and other intergovernmental authorities, as well as private and public institutions.

In order to become a Dark Sky Nation, New Zealand should create national light pollution law, which could be based on other countries' efforts, such as France [135], Great Britain [136], or Slovenia [137], as this would protect the natural environment and citizens' rights against the abuse by other people or companies, etc. This general law could then be supplemented by local lighting ordinances already in place, or be based on the IDA/IES Model Lighting Ordinance [138].

\section{LIGHT TO PROTECT THE NIGHT}

Five Principles for Responsible Outdoor Lighting
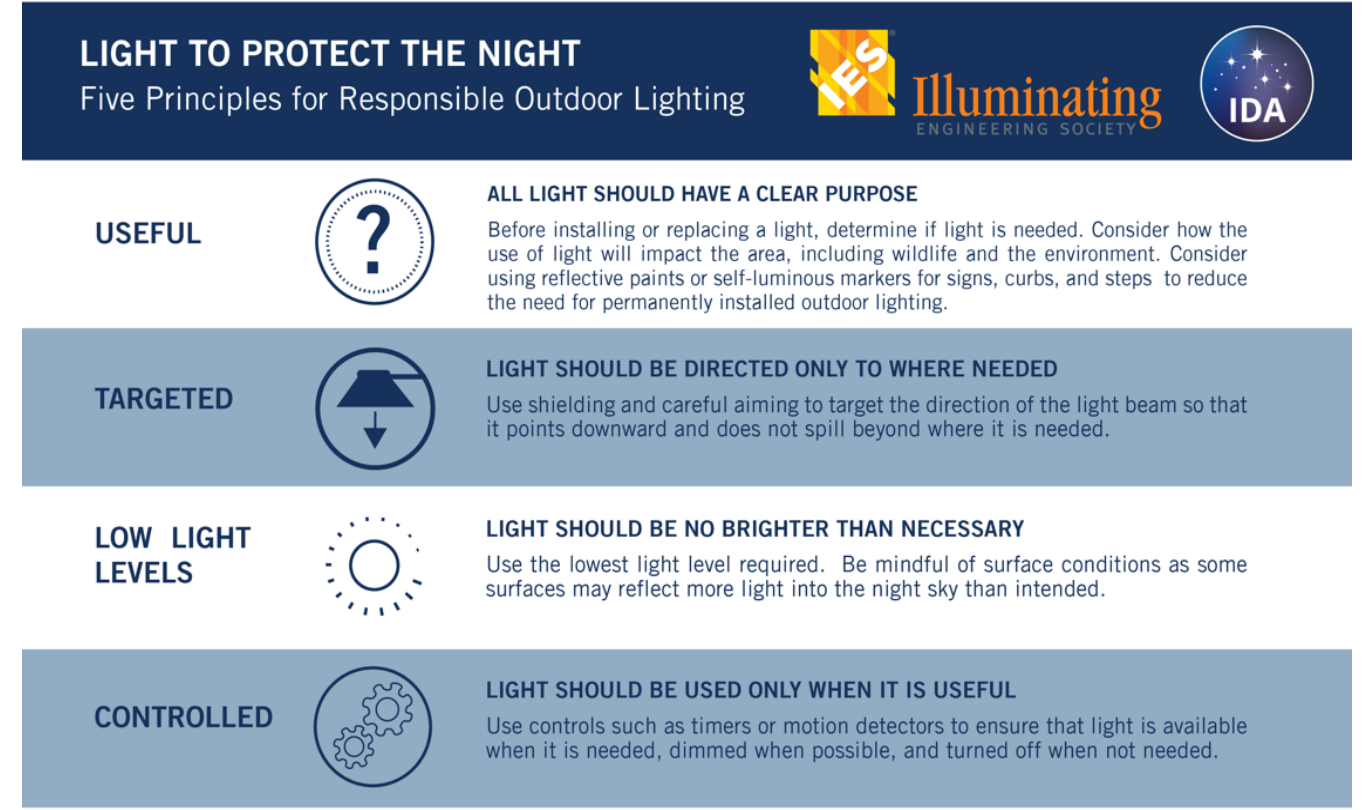

COLOR

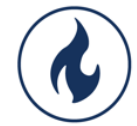

USE WARMER COLOR LIGHTS WHERE POSSIBLE

Limit the amount of shorter wavelength (blue-violet) light to the least amount needed.

Figure 6. Five Principles of Responsible Outdoor Lighting. Source: International Dark-Sky Association [139].

Author Contributions: Conceptualization, K.M.Z.-D.; methodology, K.M.Z.-D.; investigation, K.M.Z.-D.; resources, K.M.Z.-D.; writing—original draft preparation, K.M.Z.-D., with input from K.X.; writingreview and editing, K.M.Z.-D., K.X.; funding acquisition, K.M.Z.-D. All authors have read and agreed to the published version of the manuscript.

Funding: This research received no external funding, except the fee covered from the Gdansk Tech for an online gold open access publication.

Institutional Review Board Statement: Not applicable.

Informed Consent Statement: Not applicable.

Data Availability Statement: Not applicable.

Acknowledgments: The authors would like to thank the anonymous reviewers of this paper for their valuable comments. Additionally, the authors would like to thank Alejandro Sánchez de Miguel for his contribution to Figure 4. John Barentine, John Hearnshaw, Larry Field, Michele Bannister, Karen Pollard, Alan C. Gilmore, Andreas Hänel, Steve Butler, Maria Pozza and Ray Butler for useful discussions informing this work.

Conflicts of Interest: The authors declare no conflict of interest. 


\section{References}

1. New Zealand Astronomy Directory. Available online: http:/ /nzastronomy.co.nz/directory (accessed on 2 May 2021).

2. Aoraki Mackenzie (New Zealand). Available online: https://www.darksky.org/our-work/conservation/idsp/reserves/ aorakimackenzie/ (accessed on 2 May 2021).

3. Aotea/Great Barrier Island (New Zealand). Available online: https://www.darksky.org/our-work/conservation/idsp/ sanctuaries/aotea-great-barrier-island/ (accessed on 2 May 2021).

4. Stewart Island/Rakiura (New Zealand). Available online: https://www.darksky.org/our-work/conservation/idsp/sanctuaries/ stewart-island-rakiura/ (accessed on 2 May 2021).

5. First International Dark Sky Park in New Zealand Accredited. Available online: https://www.darksky.org/wai-iti-first-nz-idsp/ (accessed on 2 May 2021).

6. Fiordland 'Dark Sky Park' Would Be World's Second-Largest. Available online: https://www.rnz.co.nz/news/national/441381 / fiordland-dark-sky-park-would-be-world-s-second-largest (accessed on 2 May 2021).

7. Who We Are. Available online: https://www.darksky.org/about/ (accessed on 2 May 2021).

8. International Dark Sky Places. Available online: https://www.darksky.org/our-work/conservation/idsp/ (accessed on 2 May 2021).

9. Artificial Night Sky Brightness. Available online: https://www.stats.govt.nz/indicators/artificial-night-sky-brightness (accessed on 2 May 2021).

10. Sky-High Export Earner. Available online: https:// nzbusiness.co.nz/article/sky-high-export-earner (accessed on 2 May 2021).

11. New Zealand Named in Lonely Planet's Best of Travel for 2018. Available online: https:/ /www.tourismnewzealand.com/news/ new-zealand-named-in-lonely-planet-s-best-of-travel-for-2018/ (accessed on 2 May 2021).

12. Fayos-Solà, E.; Marín, C.; Rashidi, M.R. Astrotourism. In Encyclopedia of Tourism; Jafari, J., Xiao, H., Eds.; Springer: Cham, Switzerland, 2014. [CrossRef]

13. About the Tourism Industry. Available online: https://www.tourismnewzealand.com/about/about-the-tourism-industry/ (accessed on 2 May 2021).

14. The Summit Experience at Mt John Observatory, Lake Tekapo. Available online: https://www.discover-the-world.com/ excursions / mt-john-night-tour-dark-sky-stargazing/ (accessed on 2 May 2021).

15. Stargazing. Available online: https:/ / www.newzealand.com/int/stargazing/ (accessed on 2 May 2021).

16. Heaven's above-Star-Gazing in New Zealand. Available online: https://media.newzealand.com/en/story-ideas/heavensabove-star-gazing-in-new-zealand/ (accessed on 2 May 2021).

17. GO NZ: The Best Places to Go Stargazing in New Zealand. Available online: https:/ / www.nzherald.co.nz/travel/go-nz-thebest-places-to-go-stargazing-in-new-zealand/KCYU7DRZV5S5ELG56OA7PIKGZM/ (accessed on 2 May 2021).

18. Prime Minister Jacinda Ardern Reveals Date of First Matariki Public Holiday. Available online: https://www.rnz.co.nz/news / national/435789/prime-minister-jacinda-ardern-reveals-date-of-first-matariki-public-holiday (accessed on 2 May 2021).

19. NZ's Bid to Become First Dark Sky Nation: 'It's about Controlling Light'. Available online: https://www.rnz.co.nz/news/ national/401392/nz-s-bid-to-become-first-dark-sky-nation-it-s-about-controlling-light (accessed on 2 May 2021).

20. Rafferty, J.P. Anthropocene Epoch. Available online: https://www.britannica.com/science/Anthropocene-Epoch (accessed on 2 May 2021).

21. Cinzano, P.; Falchi, F.; Elvidge, C.D. The First World Atlas of the Artificial Night Sky Brightness. Mon. Notices R. Astron. Soc. 2001, 328, 689-707. [CrossRef]

22. Falchi, F.; Cinzano, P.; Duriscoe, D.M.; Kyba, C.C.; Elvidge, C.D.; Baugh, K.E.; Portnov, B.A.; Rybnikova, N.; Furgoni, R. The New World Atlas of Artificial Night Sky Brightness. Sci. Adv. 2016, 2, e1600377. [CrossRef] [PubMed]

23. Our Nights Are Getting Brighter, and EARTH Is Paying the Price. Available online: https://www.nationalgeographic.com/ science/article/nights-are-getting-brighter-earth-paying-the-price-light-pollution-dark-skies (accessed on 2 May 2021).

24. Light Pollution. Available online: https:/ / cie.co.at/ eilvterm/17-29-177 (accessed on 2 May 2021).

25. Man-Made Sky Glow. Available online: https: / / cie.co.at/eilvterm/17-29-179 (accessed on 2 May 2021).

26. Zielinska-Dabkowska, K.M.; Xavia, K.; Bobkowska, K. Assessment of Citizens' Actions against Light Pollution with Guidelines for Future Initiatives. Sustainability 2020, 12, 4997. [CrossRef]

27. Outer Space. Available online: https://www.lexico.com/en/definition/outer_space (accessed on 2 May 2021).

28. Near-Earth Space Is Becoming an Orbital Landfill. Available online: https://scitechdaily.com/near-earth-space-is-becoming-anorbital-landfill/ (accessed on 2 May 2021).

29. Earth's Atmosphere Stretches out to the Moon-And Beyond. Available online: https://phys.org/news/2019-02-earthatmosphere-moon.html (accessed on 2 May 2021).

30. Tourists Flock to Enjoy Tekapo's Starry Night Skies. Available online: https:/ /www.stuff.co.nz/travel/destinations/nz/116932 720 / tourists-flock-to-enjoy-tekapos-starry-night-skies (accessed on 2 May 2021).

31. New Zealand Legislation. Resource Management Act 1991 No 69(as at 13 April 2021), Public Act-New Zealand Legislation 1991. Available online: https:/ / www.legislation.govt.nz/act/public/1991/0069/latest/whole.html\#DLM231905 (accessed on 2 May 2021).

32. Jackson, T.; Dixon, J. The New Zealand Resource Management Act: An Exercise in Delivering Sustainable Development through an Ecological Modernisation Agenda. Environ. Plan. B Plan. Des. 2007, 34, 107-120. [CrossRef] 
33. An Application to the International Dark-Sky Association for a Starlight Reserve in the Aoraki/Mt Cook National Park and the Mackenzie Basin of the Central South Island of New Zealand. Available online: https://www.darksky.org/wp-content/uploads/ 2018/03/Aoraki_Mackenzie_IDSP_Application.pdf (accessed on 2 May 2021).

34. Guide to District Plan Lighting Rules on Stewart Island/Rakiura. Southland District Council. Available online: https://www. southlanddc.govt.nz/assets/have-your-say/darkskies/Lighting-guidance.pdf (accessed on 2 May 2021).

35. Dark Sky Friendly. Available online: http:/ /business.scoop.co.nz/2018/07/31/dark-sky-friendly/ (accessed on 2 May 2021).

36. Proposed Selwyn District Plan. Available online: https://www.selwyn.govt.nz/property-And-building/planning/strategiesand-plans/selwyn-district-plan/selwyn-district-plan-review (accessed on 2 May 2021).

37. Dark Sky Vision Step Closer. Available online: https:/ / www.thenews.co.nz/news/dark-sky-vision-step-closer/ (accessed on 2 May 2021).

38. Public Spaces Lighting Policy. Central Otago District Council. Available online: https://www.codc.govt.nz/repository/libraries/ id:2apsqkk8g1cxbyoqohn0/hierarchy/sitecollectiondocuments/strategies-and-policies/regulatory/Public $\% 20$ Spaces $\% 20$ Lighting\%20Policy.pdf (accessed on 2 May 2021).

39. Low Glare Street Lights Likely. Available online: https:/ /www.odt.co.nz/news/dunedin/low-glare-street-lights-likely (accessed on 2 May 2021).

40. Otago to Get Lower Level, More Expensive LED Street Lights. Available online: https:/ /www.stuff.co.nz/southland-times / news /117586965/otago-to-get-lower-level-more-expensive-led-street-lights (accessed on 2 May 2021).

41. UAU/CIE. Guidelines for Minimizing Urban Sky Glow near Astronomical Observatories (Joint Publication IAU/CIE). Available online: https:/ / cie.co.at/publications/guidelines-minimizing-urban-sky-glow-near-astronomical-observatories-jointpublication (accessed on 2 May 2021).

42. CIE. Guidelines for Minimizing Sky Glow. Available online: https:/ / cie.co.at/publications/guidelines-minimizing-sky-glow (accessed on 2 May 2021).

43. Guide on the Limitation of the Effects of Obtrusive Light from Outdoor Lighting Installations. Available online: https:/ / cie.co.at/ publications/guide-limitation-effects-obtrusive-light-outdoor-lighting-installations-2nd-edition (accessed on 2 May 2021).

44. An Investigation of LED Street Lighting's Impact on Sky Glow. Available online: https://www.energy.gov/sites/prod/files/20 17/05/f34/2017_led-impact-sky-glow.pdf (accessed on 2 May 2021).

45. AU \& NZ Standards. Available online: https:/ / www.slsc.org.au/resources/au-and-nz-standards (accessed on 2 May 2021).

46. NZ Transport Agency. M30 Specification and Guidelines for Road Lighting Design. Available online: https://www.nzta.govt.nz/ assets / resources/specification-and-guidelines-for-road-lighting-design/docs/m30-road-lighting-design.pdf (accessed on 2 May 2021).

47. Values-Centered Outdoor Lighting. Available online: https://www.darksky.org/our-work/lighting/values-centered-outdoorlighting/ (accessed on 2 May 2021).

48. NZTA Announces 85\% Contribution for LED Street Lighting Conversions. Available online: https://www.ipwea.org/blogs/ intouch/2017/03/19/nzta-announces-85-contribution-for-led-street-lighting-conversions (accessed on 2 May 2021).

49. M30 Accepted Luminaires. Available online: https://www.nzta.govt.nz/assets/resources/specification-and-guidelines-forroad-lighting-design/docs/m30-accepted-luminaires.pdf (accessed on 2 May 2021).

50. Aiming for the Stars: How New Zealand's Space Industry is Causing Turbulence. Available online: https://www.theguardian. $\mathrm{com} /$ world/2020/jan/25/aiming-for-the-stars-how-new-zealands-space-industry-is-causing-turbulence (accessed on 2 May 2021).

51. New Zealand Space Economy: Its Value, Scope and Structure. Available online: https://www.beehive.govt.nz/sites/default/ files/2019-11/Deloitte\%20NZ\%20Space\%20Economy\%20Report.pdf (accessed on 2 May 2021).

52. Witze, A. SpaceX Launch Highlights Threat to Astronomy from 'Megaconstellations'. Nature 2019, 575, 268-269. [CrossRef] [PubMed]

53. United Nations Office for Disarmament Affairs. Treaty on Principles Governing the Activities of States in the Exploration and Use of Outer Space, Including the Moon and Other Celestial Bodies. Available online: http://www.oosa.unvienna.org/oosa/ SpaceLaw / outerspt.html (accessed on 2 May 2021).

54. Too Much Light at Night Causes Spring to Come Early. Available online: https://www.nationalgeographic.com/science/article/ light-pollution-early-spring-budbursts (accessed on 2 May 2021).

55. The Dark Side of Light. Available online: https://www.theatlantic.com/science/archive/2019/09/light-pollution-destroyingenvironment/598561 (accessed on 2 May 2021).

56. Our Regulatory Regime. Available online: https://www.mbie.govt.nz/science-and-technology/space/our-regulatory-regime/ (accessed on 2 May 2021).

57. The Outer Space and High-altitude Activities Act 2017 No 29 (OSHAA). Public Act-New Zealand Legislation. New Zealand Legislation. Posted 1 December 2020. 2017. Available online: https://www.legislation.govt.nz/act/public/2017/0029/latest/ DLM6966275.html (accessed on 2 May 2021).

58. New Zealand Signs Artemis Accords. Available online: https://www.nasa.gov/feature/new-zealand-signs-artemis-accords (accessed on 22 November 2021). 
59. New Zealand Office of the Minister of Economic and Regional Development Office of the Minister of Foreign Affairs. Space Resource Utilisation and the Artemis Accords. Available online: https://www.mbie.govt.nz/dmsdocument/15305-spaceresource-utilisation-and-the-artemis-accords-proactiverelease-pdf (accessed on 2 May 2021).

60. New Zealand Drone Regulations. Available online: https://uavcoach.com/drone-laws-in-new-zealand/ (accessed on 2 May 2021).

61. Barentine, J.C. Who Speaks for the Night? The Regulation of Light Pollution in the 'Rights of Nature' Legal Framework. IJSL 2020, 22, 28-36. [CrossRef]

62. Report Published Following Workshop on Dark \& Quiet Skies for Science and Society. Available online: https://www.iau.org/ news/announcements/detail/ann21002/ (accessed on 2 May 2021).

63. Declaration in Defence of the Night Sky and the Right to Starlight. Available online: https://starlight2007.net/index_option_com_ content_view_article_id_185_starlight-declaration_catid_62_the-initiative_itemid_80_lang_en.html (accessed on 2 May 2021).

64. Revitalising Māori Astronomy. Available online: https:/ / www.sciencelearn.org.nz/resources/1274-revitalising-maori-astronomy (accessed on 2 May 2021).

65. Society of Māori Astronomy Research \& Traditions. Available online: https://www.maoriastronomy.co.nz/ (accessed on 2 May 2021).

66. Harris, P.; Matamua, R.; Smith, T.; Kerr, H.; Waaka, T. A Review of Māori astronomy in Aotearoa-New Zealand. J. Astron. Hist. Herit. 2013, 16, 325-336. Available online: https:/ /www.researchgate.net/publication/260939222_A_review_of_Maori_ astronomy_in_Aotearoa-New_Zealand (accessed on 2 May 2021).

67. Listen: Matariki and Māori astronomy with Dr Rangi Matamua. Available online: https://www.tepapa.govt.nz/discovercollections / read-watch-play/maori/matariki-maori-new-year/listen-matariki-and-maori (accessed on 6 December 2021).

68. Reviving Ancient Māori Knowledge. Available online: https://www.wgtn.ac.nz/maori-hub/rangahau/maori-research-projects/ reviving-ancient-maori-knowledge (accessed on 2 May 2021).

69. Starlight Initiative and the La Palma Declaration. Available online: https://www.ramsar.org/news/starlight-initiative-and-thela-palma-declaration (accessed on 2 May 2021).

70. Central Christchurch to Be Lit up for Matariki. Available online: https://www.stuff.co.nz/the-press/news/300287753/centralchristchurch-to-be-lit-up-for-matariki (accessed on 2 May 2021).

71. Sánchez de Miguel, A.; Bennie, J.; Rosenfeld, E.; Dzurjak, S.; Gaston, K.J. First Estimation of Global Trends in Nocturnal Power Emissions Reveals Acceleration of Light Pollution. Remote Sens. 2021, 13, 3311. [CrossRef]

72. Hearnshaw, J.B.; Gilmore, A. Mt John, the First 50 Years: A Celebration of Half a Century of Optical Astronomy at the University of Canterbury; Canterbury University Press: Cantenbury, New Zealand, 2015.

73. TEARA. The Encyclopedia of New Zealand. Story: Astronomy-Overview. Available online: https://teara.govt.nz/en/astronomyoverview / page-2 (accessed on 22 November 2021).

74. Orchiston, W. John Grigg, and the Genesis of Cometary Astronomy in New Zealand. In Exploring the History of New Zealand Astronomy; Astrophysics and Space Science Library, Springer: Cham, Switzerland, 2016. [CrossRef]

75. TEARA. The Encyclopedia of New Zealand. Story: Kennedy, David. Available online: https://teara.govt.nz/en/biographies/ 3k8/kennedy-david (accessed on 22 November 2021).

76. Albert Jones-The Quiet Achiever. Available online: https:/ /web.archive.org/web/20070927211108/ (accessed on 22 November 2021).

77. Supernova 2009gj in NGC 134. Available online: https:/ / ui.adsabs.harvard.edu/abs/2009CBET.1856....1M/abstract (accessed on 22 November 2021).

78. Long Look into Night Finds Explosion of Light. Available online: https://www.stuff.co.nz/science/2564450/Long-look-intonight-finds-explosion-of-light (accessed on 22 November 2021).

79. Amateurs Help Discover Exoplanet. Available online: https://skyandtelescope.org/astronomy-news/amateurs-help-discoverexoplanet/ (accessed on 22 November 2021).

80. Tiniest Extrasolar Planet Found. Available online: http://news.bbc.co.uk/2/hi/science/nature/7432114.stm (accessed on 22 November 2021).

81. Herrera-Martín, A.; Albrow, M.D.; Udalski, A.; Gould, A.; Ryu, Y.-H.; Yee, J.C.; Chung, S.-J.; Han, C.; Hwang, K.-H.; Jung, Y.K.; et al. OGLE-2018-BLG-0677Lb: A Super-Earth near the Galactic Bulge. AJ 2020, 59, 256. [CrossRef]

82. Category: Astronomical Observatories in New Zealand. Available online: https://en.wikipedia.org/wiki/Category: Astronomical_observatories_in_New_Zealand (accessed on 2 May 2021).

83. 5G: Using Drones to Beam Signals from the Stratosphere. Available online: https://www.bbc.com/news/technology-54797917 (accessed on 2 May 2021).

84. 5G from Space-The Role of Satellites in 5G. Available online: https://www.nokia.com/networks/insights/5g-space-satellites/ (accessed on 13 May 2021).

85. Industry Voices-Menon: Satellite Mega-Constellations Are Connectivity's New Frontier Post-5G Revolution. Available online: https:/ / www.fiercetelecom.com/telecom/industry-voices-menon-satellite-mega-constellations-are-connectivity-s-newfrontier-post-5g (accessed on 15 October 2021).

86. Will 5G Make Earth-Bound Radio Telescopes Impractical? Available online: https://www.testandmeasurementtips.com/will-5gmake-earth-bound-radio-telescopes-impractical-faq/ (accessed on 2 May 2021). 
87. International Telecommunication Union (ITU). Handbook on Radio Astronomy. 2013 3rd Edition, p. 54. Available online: https://www.itu.int/dms_pub/itu-r/opb/hdb/R-HDB-22-2013-PDF-E.pdf (accessed on 2 May 2021).

88. Drone Light Shows. Available online: https://skymagic.show/ (accessed on 2 May 2021).

89. New Zealand Drone Light Shows. Available online: https://www.hireuavpro.com/item/new-zealand-drone-light-shows/ (accessed on 2 May 2021).

90. Zielinska-Dabkowska, K.M. Make Lighting Healthier. Nature 2018, 553, 274-276. [CrossRef] [PubMed]

91. Spill Light. Available online: https:/ / cie.co.at/ eilvterm/17-29-185 (accessed on 2 May 2021).

92. Tähkämö, L.; Partonen, T.; Pesonen, A.K. Systematic Review of Light Exposure Impact on Human Circadian Rhythm. Chronobiol. Int. 2019, 36, 151-170. [CrossRef] [PubMed]

93. Drones Can Do Serious Damage to Airplanes, Video Shows. Available online: https://eu.usatoday.com/story/travel/nationnow /2018/10/17/drones-crashing-into-airplanes-quadcopters-damage-video/1657112002/ (accessed on 2 May 2021).

94. Hölker, F.; Wolter, C.; Perkin, E.K.; Tockner, K. Light Pollution as a Biodiversity Threat. Trends Ecol. Evol. 2010, 25, 681-682. [CrossRef] [PubMed]

95. Gaston, K.J.; Bennie, J.; Davies, T.W.; Hopkins, J. The Ecological Impacts of Nighttime Light Pollution: A Mechanistic Appraisal. Biol. Rev. 2013, 88, 912-927. [CrossRef] [PubMed]

96. From Dung Beetles to Seals, These Animals Navigate by the Stars. Available online: https://www.nationalgeographic.com/ animals/article/stars-milky-way-navigation-dung-beetles (accessed on 2 May 2021).

97. Irwin, A. The Dark Side of Light: How Artificial Lighting is Harming the Natural World. Nature 2018, 553, 268-270. [CrossRef] [PubMed]

98. New Zealand Moths. Available online: https://www.sciencelearn.org.nz/resources/2446-new-zealand-moths (accessed on 2 May 2021).

99. Velvet Underground. Available online: https://www.nzgeo.com/stories/velvet-underground/ (accessed on 2 May 2021).

100. Little Penguin/Kororā. Available online: https://www.doc.govt.nz/nature/native-animals/birds/birds-a-z/penguins/littlepenguin-korora/ (accessed on 2 May 2021).

101. Forest \& Bird Calls for Urgent Action to Save Hamilton Bats. Available online: https://www.forestandbird.org.nz/resources/ forest-bird-calls-urgent-action-save-hamilton-bats (accessed on 2 May 2021).

102. Wild Nightlife. Available online: https:/ /www.forestandbird.org.nz/resources/wild-nightlife (accessed on 2 May 2021).

103. Morepork/Ruru. Available online: https://www.doc.govt.nz/nature/native-animals/birds/birds-a-z/morepork-ruru/ (accessed on 2 May 2021).

104. Facts and Threats to Kiwi. Available online: https://www.doc.govt.nz/nature/native-animals/birds/birds-a-z/kiwi/facts/ (accessed on 2 May 2021).

105. New Zealand's Glow-Worms. Available online: https://teara.govt.nz/en/glow-worms/page-1 (accessed on 2 May 2021).

106. Wētā. Available online: https://wwww.doc.govt.nz/nature/native-animals/invertebrates/weta/ (accessed on 2 May 2021).

107. Lewis, S.A.; Thancharoen, A.; Wong, C.H.; López-Palafox, T.G.; Santos, P.V.; Wu, C.; Faust, L.F.; De Cock, R.; Owens, A.C.; Lemelin, R.H. Firefly Tourism: Advancing a Global Phenomenon toward a Brighter Future. Conserv. Sci. Pract. 2021, 3, e391. [CrossRef]

108. Lundquist, D.; Gemmell, N.J.; Würsig, B.; Markowitz, T. Dusky Dolphin Movement Patterns: Short-Term Effects of Tourism. N. Z. J. Mar. Freshw. Res. 2013, 47, 430-449. [CrossRef]

109. Hutton's Shearwater/Kaikōura tìtī. Available online: https://www.doc.govt.nz/nature/native-animals/birds/birds-a-z/ huttons-shearwater-kaikoura-titi/ (accessed on 2 May 2021).

110. Buler, J.J.; Cabrera-Cruz, S.A.; Smolinsky, J.A. Light Pollution Is Greatest within Migration Passage Areas for NocturnallyMigrating Birds around the World. Sci. Rep. 2018, 8, 3261.

111. A Generation of Seabirds was Wiped Out by a Drone in O.C. Scientists Fear for Their Future. Available online: https://www. latimes.com/california/story/2021-06-07/thousands-of-eggs-abandoned-after-drone-crash-at-orange-county-nature-reserve (accessed on 2 May 2021).

112. 1500 Eggs Were Waiting to Hatch. Then a Drone Crashed. Available online: https://www.nytimes.com/2021/06/04/us/eleganttern-eggs-drone-crash-california.html?smid=fb-nytimes\&smtyp=cur (accessed on 2 May 2021).

113. Drone. Lights. Camera. Art. “Space-Time Sculptures” Create One-of-a-Kind Works of Art in Colorado's Mountains. Available online: https: / / coloradosun.com/2020/06/26/drone-light-sculpture-breckenridge/ (accessed on 2 May 2021).

114. Global Light Pollution Is Affecting Ecosystems-What Can We Do? Available online: https://www.unep.org/news-and-stories/ story/global-light-pollution-affecting-ecosystems-what-can-we-do (accessed on 2 May 2021).

115. 'We've Left Junk Everywhere': Why Space Pollution Could Be Humanity's Next Big Problem. Available online: https: //www.theguardian.com/science/2017/mar/26/weve-left-junk-everywhere-why-space-pollution-could-be-humanitysnext-big-problem (accessed on 2 May 2021).

116. Britannica, T. Editors of Encyclopaedia. "Sputnik". Available online: https:/ / www.britannica.com/technology/Sputnik (accessed on 2 May 2021).

117. Who Owns Our Orbit: Just How Many Satellites Are There in Space? Available online: https://www.weforum.org/agenda/2020 /10/visualizing-easrth-satellites-sapce-spacex/ (accessed on 2 May 2021). 
118. Space Debris and Human Spacecraft. Available online: https://www.nasa.gov/mission_pages/station/news/orbital_debris. html (accessed on 2 May 2021).

119. 2009 Satellite Collision. Available online: https:/ / en.wikipedia.org/wiki/2009_satellite_collision (accessed on 2 May 2021).

120. The Elusive Peril of Space Junk. Available online: https://www.newyorker.com/magazine/2020/09/28/the-elusive-peril-ofspace-junk (accessed on 2 May 2021).

121. Ecuador Pegasus Satellite Fears over Space Debris Crash. Available online: https://www.bbc.com/news/world-latin-america22635671 (accessed on 2 May 2021).

122. A Piece of Space Junk Zipped by SpaceX's Dragon Capsule on Its Way to the Space Station. Available online: https: / / www.space. com/spacex-crew-2-dragon-capsule-space-junk (accessed on 2 May 2021).

123. Hänel, A.; Posch, T.; Ribas, S.J.; Aube, M.; Duriscoe, D.M.; Jechow, A.; Kolláth, Z.; Lolkema, D.; Moore, C.A.; Schmidt, N.; et al. Measuring Night Sky Brightness: Methods and Challenges. J. Quantit. Spectrosc. Radiat. Transf. 2018, 205, 278-290. [CrossRef]

124. Dark and Quiet Skies for Science and Society. Available online: http:/ / research.iac.es/congreso/quietdarksky2020/ (accessed on 2 May 2021).

125. The 17 Goals. Available online: https://sdgs.un.org/goals (accessed on 2 May 2021).

126. Mika, J.; Apró, A. Connections of the Light Pollution Issue to the Un Sustainable Development Goals. Acta Universitatis de Carolo Eszterházy Nominatae. Sect. Biol. 2021, 46, 183-192. [CrossRef]

127. Strong, S.I. International Litigation-Arbitration. In Encyclopedia of Law and Economics; Marciano, A., Ramello, G.B., Eds.; Springer: New York, NY, USA, 2021. [CrossRef]

128. Democratizing Access to Space. Available online: https:/ /www.media.mit.edu/posts/democratizing-access-to-space/ (accessed on 2 May 2021).

129. Clean Space. Available online: https:/ / www.esa.int/Safety_Security/Clean_Space (accessed on 2 May 2021).

130. ESA's Space Environment Report 2021. Available online: https://www.esa.int/Safety_Security/Space_Debris/ESA_s_Space_ Environment_Report_2021 (accessed on 2 May 2021).

131. The Future of Space Tourism: Op-Ed. Available online: https:/ /www.space.com/future-of-space-tourism-op-ed (accessed on 2 May 2021).

132. New Zealand Needs to Use 'All the Tools in Its Toolbox' to Become a Dark Sky Nation. Available online: https: / / www.stuff.co.nz/ timaru-herald/news /116766923/new-zealand-needs-to-use-all-the-tools-in-its-toolbox-to-become-a-dark-sky-nation?rm=a (accessed on 2 May 2021).

133. ABOUT the IAU. Available online: https:/ /www.iau.org/administration/about/ (accessed on 2 May 2021).

134. About Us. Available online: https:/ /www.unoosa.org/oosa/en/aboutus/index.html (accessed on 2 May 2021).

135. Journal of Laws of the French Republic of 28 December 2018, No. 17, Item 197. Available online: https:/ / www.legifrance.gouv.fr/ loda/id/JORFTEXT000037864346/ (accessed on 4 November 2021).

136. Guidance Light Pollution. Available online: https://www.gov.uk/guidance/light-pollution (accessed on 2 May 2021).

137. Light Pollution Law. Slovenia 2007. Available online: http://www.fao.org/faolex/results/details/en/c/LEX-FAOC084337 (accessed on 2 May 2021).

138. Model Lighting Ordinance. Available online: https://www.darksky.org/our-work/lighting/public-policy/mlo/ (accessed on 2 May 2021).

139. Five Principles for Responsible Outdoor Lighting. Available online: https:/ /www.darksky.org/our-work/lighting/lightingprinciples/ (accessed on 2 May 2021). 